\title{
COMMON RAIL INJECTOR LEAK TESTING
}

\section{CELESTÝN SCHOLZ, PETR STARÝ}

Technical University of Liberec, Studentská 2, 46117 Liberec, e-mail: celestyn.scholz@tul.cz, stary.petr@seznam.cz

\section{SHRNUTí}

Článek popisuje obecné možnosti zjištování vnitřní a vnější těsnosti jednotlivých částí injektoru pro vysokotlaký palivový systém Common Rail. Na konkrétním injektoru Bosch pro motor Cummins se presentuje vlastní metoda měření těsnosti trysky, kuličkového ventilu a vnitřní části tyčky ovládající jehlu trysky. Testování této vnitřní části injektoru je důležité pro ověření vlivu úprav, které jsou potřebné pro měření a výzkum pohybu jehly trysky.

\section{KLIIČOVÁ SLOVA: COMMON RAIL, INJEKTOR, JEHLA TRYSKY, KULIČKOVÝ VENTIL, NETĚSNOST, TESTOVÁNÍ}

\section{ABSTRACT}

The article describes some general options for detection of internal and external leakage from individual parts of an injector for the high pressure Common Rail fuel system. Our own method of measuring leakage of the nozzle, ball valve and the inner part of the bar controlling the needle nozzle is presented with respect to a particular Bosch injector for the Cummins engine. Testing of the inner part of the injector is important for verifying the effect of the adjustments that are needed for measurement and research of the motion of the needle nozzle.

KEYWORDS: COMMON RAIL, INJECTOR, NEEDLE NOZZLE, BALL VALVE, LEAK, TESTING.

\section{INTRODUCTION}

The compression ignition (Diesel) engine is the most energy efficient driving unit, and it will continue to be the main source of mechanical energy, in particular in the field of the transport of persons and merchandise. In this area of application, compression ignition engines are subject to ever greater reductions in the limits of noxious agents contained in exhaust gases, in order to reduce impact on the living environment. In the last 20 years, the limits for harmful constituents have been reduced by nearly $90 \%$. This development motivates the manufacturers of compression ignition engines to research new strategies for fuel injection, combustion, supercharging, complementary cleaning of exhaust gases, and to implement electronic control of engine functions. In the area of fuel injection, the prevailing trend is the increase of injection pressures, required for fine atomization of the fuel before its ignition in the engine cylinder.

With respect to compression ignition engines used to drive road vehicles, the present standard is the accumulator fuel system of the Common Rail type. It best meets the requirements concerning the reduction of noxious agents in the combustion products, low fuel consumption and quiet running of the engine at reasonable production costs. It enables achievement of not only the required high injection pressures independent of the engine rpm, but also flexibility of timing, distribution and shaping of individual sections of the injection.

The high injection pressure strains the individual components of the injection system and causes leaks in movable and contact places. The injection nozzle, the ball control valve and sliding fit of the piston are affected continuously by high fuel pressure, which requires new manufacturing and service procedures in order to safeguard their long-term tightness. In manufacture, the issues are the precision of machining, combined with narrow tolerances and precise mating, and the removal of the remains of solid particles from the manufacturing process. In service, checking operations monitoring the tightness of the nozzle and measuring of the quantity of fuel return is important. It is possible for the tightness to fail even due to very small admixtures contained in the fuel. Therefore, during the engine operation it is important to ensure the cleanliness of the fuel coming from the tank to the Common Rail fuel system.

Leak rate can generally be defined as a mass or volume flow of the medium out of the checked content or into it. It occurs in the components closing the flow, such as valves and sealing elements. 
In order to establish the significance of the factors influencing the leaks, it is possible to employ the Hagen-Poiseuille formula (1) from publication [1], which describes the volume flow through a pinhole:

$$
Q=k \cdot \frac{d^{4}}{L} \cdot \frac{\Delta p}{\mu}
$$

In this equation: $Q$ is the volumetric leak flow rate $\left(\mathrm{cm}^{3} / \mathrm{min}\right) ; k$ is a constant defined during calibration; $d$ is the pinhole diameter $(\mathrm{cm}) ; L$ is the length of the flow path $(\mathrm{cm}) ; \Delta p$ is the differential across the flow path ( $\mathrm{kPa}), \mu$ is fluid viscosity ( $\mu \mathrm{Pa}$. $s)$.

The sample shows that the magnitude of the leak flow depends on three principal factors:

1. geometry of the defect, where the diameter of the hole significantly predominates over the length of pass of the medium through the defect,

2. properties of the medium, and in particular its viscosity. A high viscosity displays a lower leak flow at the same defect and same difference of pressures. Consequently, the use of air or nitrogen produces a considerably higher leak rate than the use of a liquid, which increases the sensitivity of the test when testing lack of tightness,

3. difference of pressures in the path of the flow. Increase of the pressure difference between the sealed content and the surroundings increases the volumetric flow through the leak; however, for gas this applies only until the gas flow reaches the velocity of sound.

To measure the flow through a leak, indirect methods employing calculations are used (informative bubble method and measuring based on pressure decrease), or methods of direct measurement of the mass flow through the leak. The direct methods are based on the law of conservation of mass.

$m_{I N}=m_{\text {OUT }}+d m$

In this equation:

$m_{I N} \quad \begin{aligned} & \text { is the mass flow supplied to the measured object } \\ & \text { during the test, }\end{aligned}$
$m_{\text {OUT }} \quad \begin{aligned} & \text { is the mass flow escaping from the measured } \\ & \text { object, }\end{aligned}$
$d m \quad \begin{aligned} & \text { is the additional mass accumulated during the } \\ & \text { test. }\end{aligned}$

$d m=0 \quad \ldots$ provided that the pressure and temperature in the object are constant during the test. Under this condition, the mass flow supplied to the object equals the mass flow escaping through the leak.

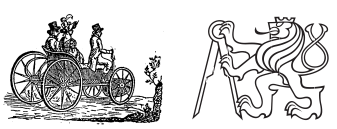

The method of direct measuring of the mass flow, established by measuring the mass over a certain period, has been employed for experiments with internal and external leakage of the injector of the Common Rail fuel system.

\section{PREPARATION OF THE EXPERIMENT}

For measuring the leaks of the Common Rail injector, an experimental stand designed for the research of high-pressure injectors in general was used. The basic version of the stand (shown in Figure 1) has been described in the publication [2].

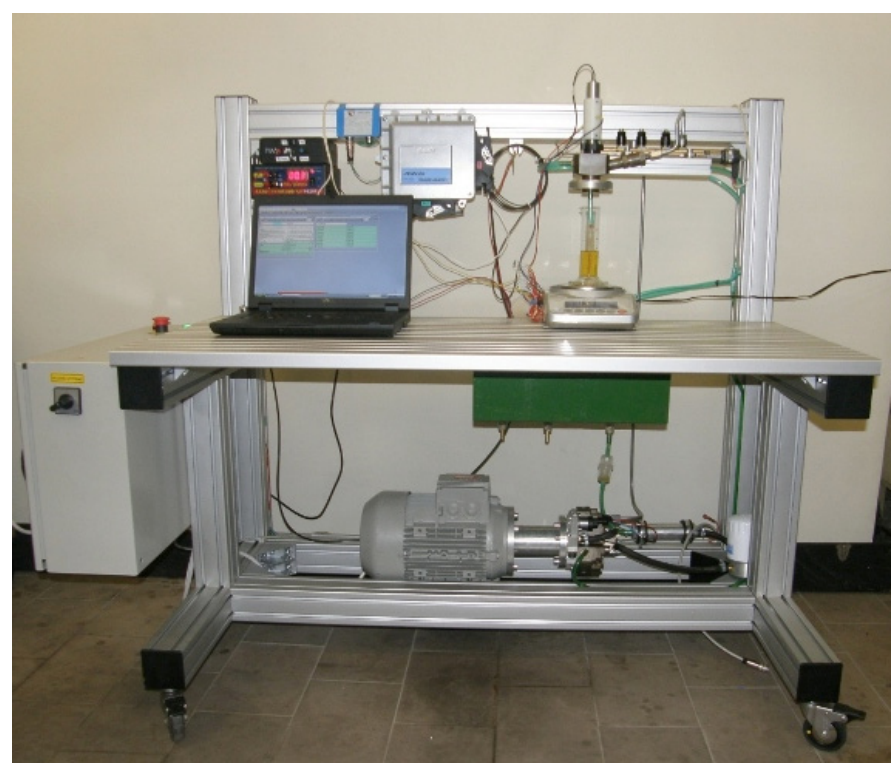

FIGURE 1: Overall configuration of the experimental stand for Common Rail injectors

OBRÁZEK 1: Celkové uspořádání zkušební stanice pro Common Rail injektory.

A constant pressure of the fuel entering the injector is secured by the high-pressure section of the stand, modelling the real condition of the 4-cylinder Cummins ISBe-4 engine. Original Bosch components have been used (high pressure pump, Rail, valve governing the pressure in the Rail). The fuel pressure was checked using the Kistler $4618 \mathrm{~A} 2$ sensor. The fuel temperature is measured with the PT 100 sensor placed at the input to the highpressure fuel pump. The high-pressure injector Bosch 2330957 has been adapted for measuring the stroke of the needle by means of the pick-up Robert Bosch LS04 (shown in Figure 2), see the publication [2], with the aid of a Micro Epsilon measuring appliance.

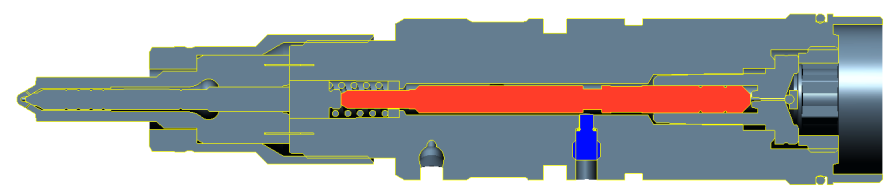

FIGURE 2: Incorporation of the pick-up in the body of the injector OBRÁZEK 2: Zabudování senzoru pohybu v tělese injektoru. 
The Helago FX-300iWP scale, with a range up to $320 \mathrm{~g}$ and accuracy of reading $0.001 \mathrm{~g}$, was used to measure fuel weight. For measuring the mass flow through the leak in $\mathrm{g} / \mathrm{min}$ with the injector in the closed condition, time was registered. When measuring the mass flow in g/cycle, with the injector activated repeatedly, corresponding to an engine rpm of 1.500 , the total number of cycles was registered.

Figure 3 describes the main components of the employed type of injector.

Figure 4 shows the fuel conduct lines and their adjustment. The highly pressurized fuel is directed from the rail to the injectors. Then it passes to the nozzle and to the valve control chamber. The nozzle of the injector is open when the solenoid is actuated and permits the flow of excessive fuel back to the tank.

The return flow of fuel to the tank consists of fuel which was required for opening the nozzle and passes through the ball valve of the actuated solenoid, and of the fuel which escapes through the leaks in the guiding of the needle and of the cylindrical piston. We can separate these flows from one another by closing the connecting channel.

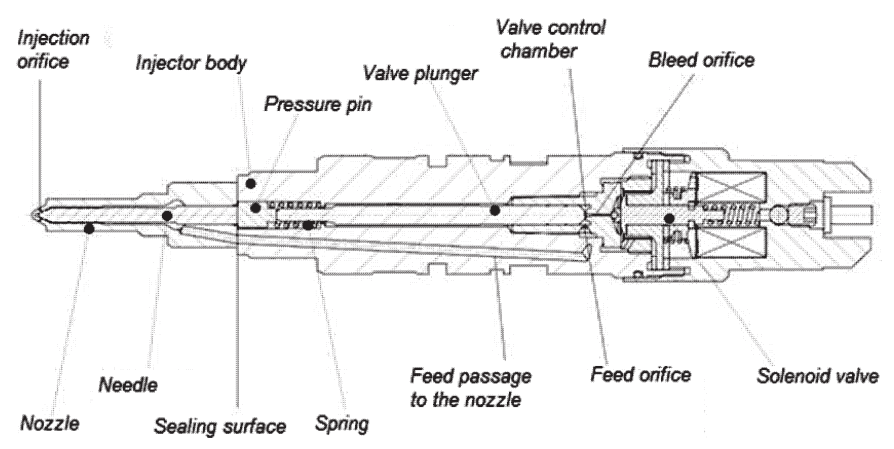

FIGURE 3: Description of injector components OBRÁZEK 3: Popis částí injektoru.

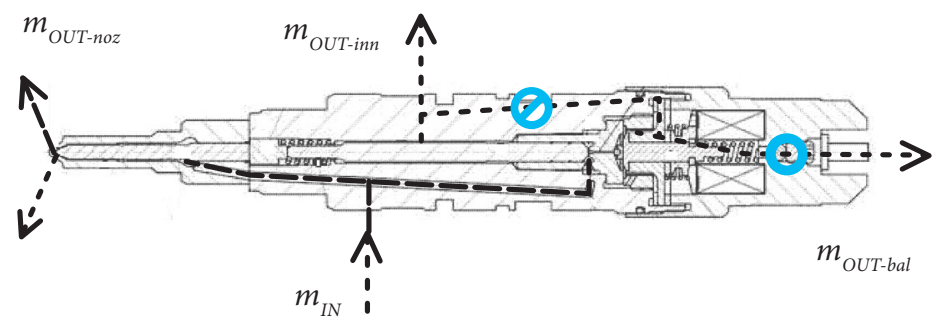

Explanation of symbols:

(O) - interruption of the line

- opening of the line

FIGURE 4: Visualisation of the fuel conduct lines in the injector from the input to the outputs after adjustment.

OBRÁZEK 4: Znázornění cest vedení paliva v injektoru od vstupu k výstupům po úpravě.
The following equation applies:

$m_{\text {IN }}=m_{\text {OUT-noz }}+m_{\text {OUT-inn }}+m_{\text {OUT-bal }}$

The flow mass quantities in the equation (3), visualised in Figure 2, stand for:

$\begin{array}{ll}m_{\text {IN }} & \begin{array}{l}\text { fuel entering the injector } \\ m_{\text {OUT-noz }} \\ \text { fuel injected through the open nozzle into the } \\ \text { engine cylinder, } \\ \text { fuel dripping through loose closed nozzle }\end{array} \\ & \begin{array}{l}\text { fuel escaping through internal leaks in the } \\ \text { guiding of the needle and of the cylindrical }\end{array} \\ & \begin{array}{l}\text { piston } \\ \text { fuel flowing back to the tank at the opening } \\ \text { of the ball valve actuated by the solenoid } \\ \text { (nozzle opened) }\end{array} \\ & \text { fuel escaping through loose ball valve at closed } \\ & \text { nozzle (not actuated solenoid) }\end{array}$

\section{MEASUREMENTS AND THEIR}

\section{EVALUATION}

Before taking measurements, the test injector with built-in sensor of the needle stroke was checked for leaks of the nozzle and ball valve, and for internal leaks in the guiding of the needle and of the cylindrical piston. After replacement of the nozzle and the solenoid with ball valve, its leak rate matched that of a standard new injector.

Measurements of mass flows in the fuel leaks with closed nozzle (the solenoid not actuated) and fuel flows during multiple actuation of the solenoid at a frequency corresponding to the engine speed of 1,500 rpm were performed using this injector. The length of actuation corresponded to periods of 5, 10 and $15^{\circ} \mathrm{CA}$. The effect of the input pressure of the fuel in the range $70-160 \mathrm{MPa}$ upon flows and leaks was investigated.

From Figure 5 it follows that with the closed nozzle (solenoid not actuated) the tightness of the nozzle is $100 \%$ across the whole range of pressures. The internal leaks of the guiding of the nozzle and of the cylindrical piston at fuel temperature $40^{\circ} \mathrm{C}$ become evident at $120 \mathrm{MPa}$. The ball valve shows a lack of tightness at $150 \mathrm{MPa}$, which increases considerably at $160 \mathrm{MPa}$.

From Figure 6 it follows that the tightness of the nozzle is also $100 \%$ across the whole range of pressures at a fuel temperature of $15^{\circ} \mathrm{C}$. The inner leak rate of the guiding of the nozzle and of the cylindrical piston becomes apparent in nearly the same way as at the higher temperature of $40^{\circ} \mathrm{C}$. However, the ball valve displays greater tightness. The valve shows no leaks up to $150 \mathrm{MPa}$, and at $160 \mathrm{MPa}$, the leak rate amounts to $3 \mathrm{~g} / \mathrm{min}$. 


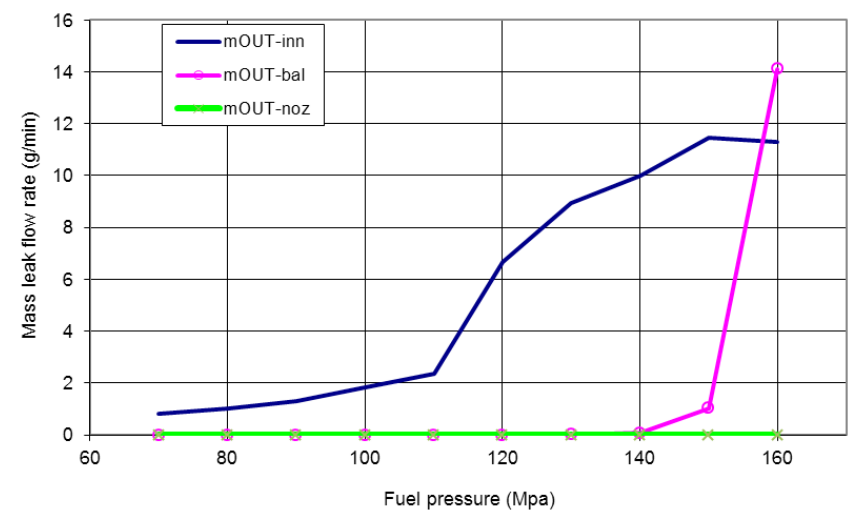

FIGURE 5: Effect of increasing fuel pressure upon the level of mass leaks in the individual sections with the injector nozzle closed at fuel temperature $40^{\circ} \mathrm{C}$.

OBRÁZEK 5: Vliv zvyšování tlaku paliva na miře hmotové netěsnosti v jednotlivých částech při zavřené trysce injektoru při teplotě paliva $40^{\circ} \mathrm{C}$.

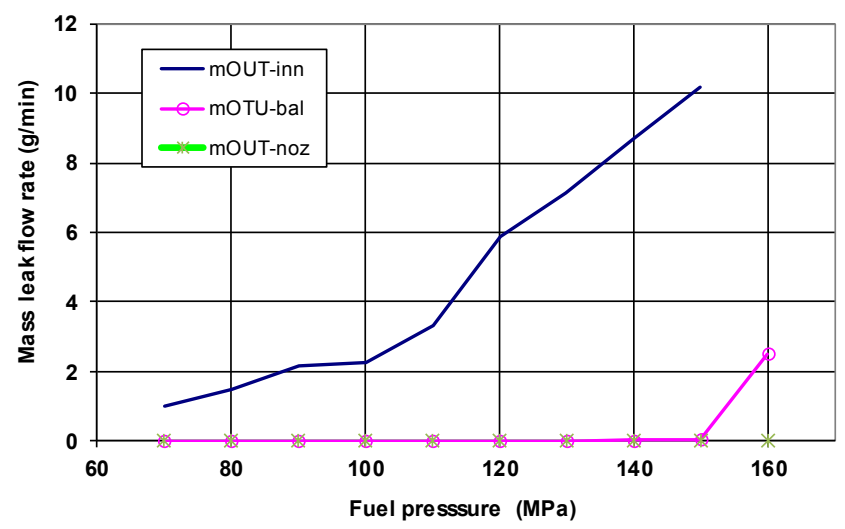

FIGURE 6: Effect of increasing fuel pressure upon the level of mass leaks in the individual sections with the injector nozzle closed at fuel temperature $15^{\circ} \mathrm{C}$.

OBRÁZEK 6: Vliv zvyšování tlaku paliva na míře hmotové netěsnosti $v$ jednotlivých částech při zavřené trysce injektoru při teplotě paliva $15^{\circ} \mathrm{C}$.
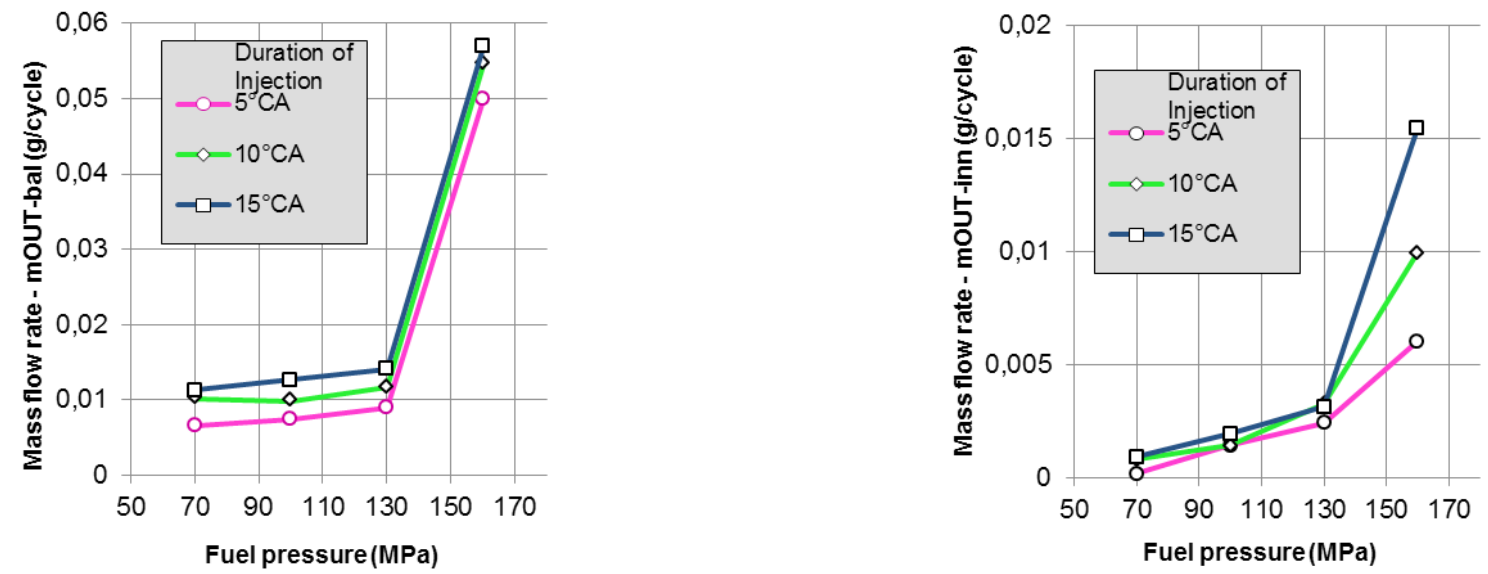

FIGURE 7: Effect of increasing fuel pressure upon the level of mass flow through the opened ball valve (left); the leaks in the guiding of the needle and of the cylindrical piston (right). Measured at a temperature of $40^{\circ} \mathrm{C}$.

OBRÁZEK 7: Vliv zvyšování tlaku paliva na hmotový průtok otevřeným kuličkovým ventilem (vlevo), netěsnost vedením jehly a válcového pístu (vpravo). Měřeno prì teplotě $40^{\circ} \mathrm{C}$.

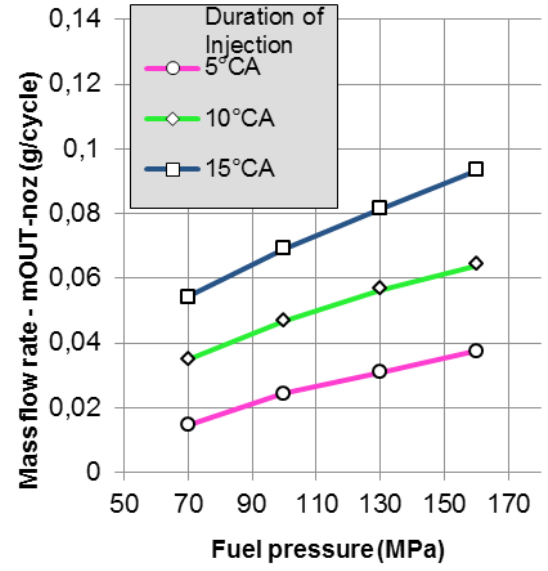

FIGURE 8: Effect of increasing fuel pressure upon the level of mass flow through the opened nozzle (measured at a temperature of $40^{\circ} \mathrm{C}$ ) OBRÁZEK 8: Vliv zvyšování tlaku paliva na hmotový průtok otevřenou tryskou (měřeno při teplotě $40^{\circ} \mathrm{C}$ ). of the mass flow. Individual data points are the result of the arithmetic mean of three values, with each measurement taking place over 10 minutes.

The following figures 7,8 and 9 show the progress of the fuel cycle programs depending on the pressure and the length of opening of the electromagnet. Individual points were determined as the arithmetic mean of three values, wherein each value contained 2000 cycle program doses.

From Figure 7 (left) it follows that the flow through the opened ball valve of the solenoid (primary part of the return flow of fuel to the tank) increases moderately with the interval of its opening. The effect of the input pressure upon the flow is insignificant up to the value of $130 \mathrm{MPa}$, after which it increases sharply. From Figure 7 (right) it follows that the flow through an internal leak in the guiding of the needle and of the cylindrical control piston (secondary part of the return flow to the tank) increases with input 

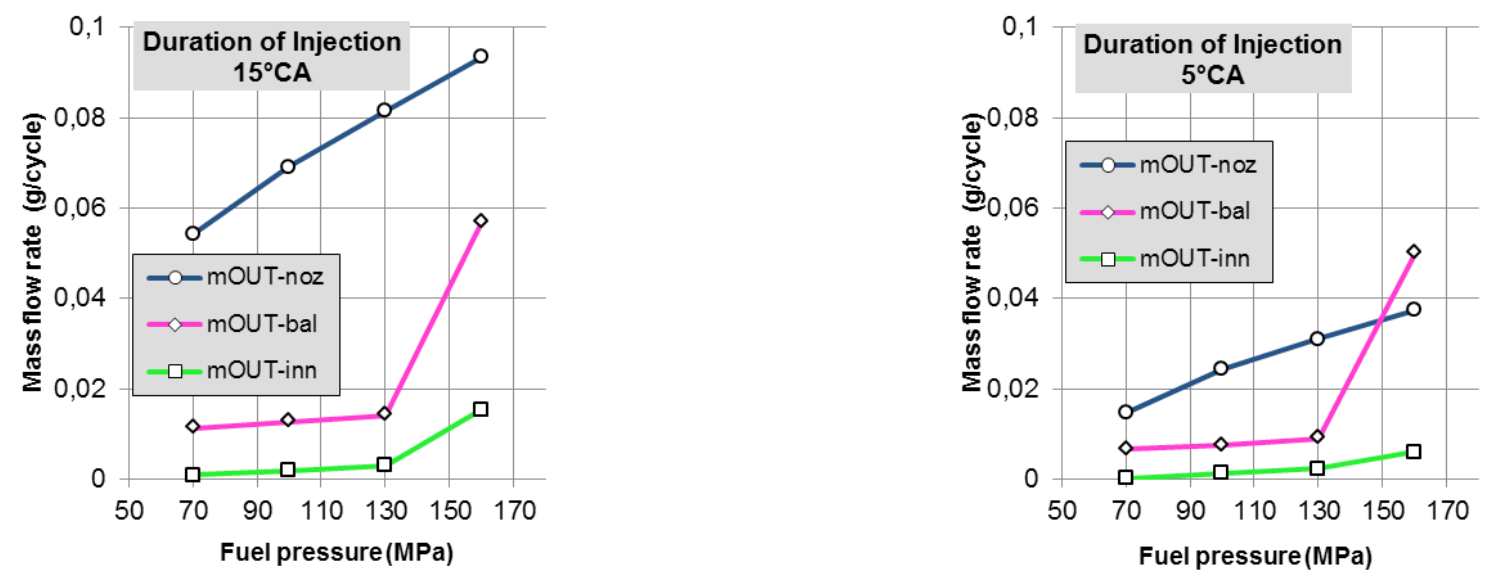

FIGURE 9: Effect of increasing fuel pressure upon the level of the mass flow of all three lines at a constant period of solenoid actuation $15^{\circ} \mathrm{CA}$ (left) and $5^{\circ} \mathrm{CA}$ (right). Measured at a temperature of $40^{\circ} \mathrm{C}$.

OBRÁZEK 9: Vliv zvyšování tlaku paliva na hmotových průtocích všech tří cest při konstantní délce aktivace solenoidu $15^{\circ} \mathrm{CA}$ (vlevo), a $5^{\circ} \mathrm{CA}$ (vpravo). Měřeno při $40^{\circ} \mathrm{C}$.

pressure of the fuel. The effect of the interval of opening in the cycle is significant only at fuel pressures exceeding $130 \mathrm{MPa}$.

From Figure 8 it follows that the flow through the open nozzle (dose of fuel injected into the engine cylinder) increases with the pressure and with the period of nozzle opening during the operating cycle of the engine.

From Figure 9 (left) it follows that during longer openings of the nozzle (actuations of the solenoid $15^{\circ} \mathrm{CA}$ ), the flow through the nozzle is dominant; however, at high pressure the difference decreases in comparison with the flow of fuel returning to the tank. From Figure 9 (right) it follows that at shorter openings of the nozzle (actuation of the solenoid $5^{\circ} \mathrm{CA}$ ) from a pressure of $130 \mathrm{MPa}$ upwards, the flow of fuel returning to the tank is already dominant.

Figures 5 to 9 show that the injector has the greatest leakage in the areas above $140 \mathrm{MPa}$. It wasn't proven that these significant

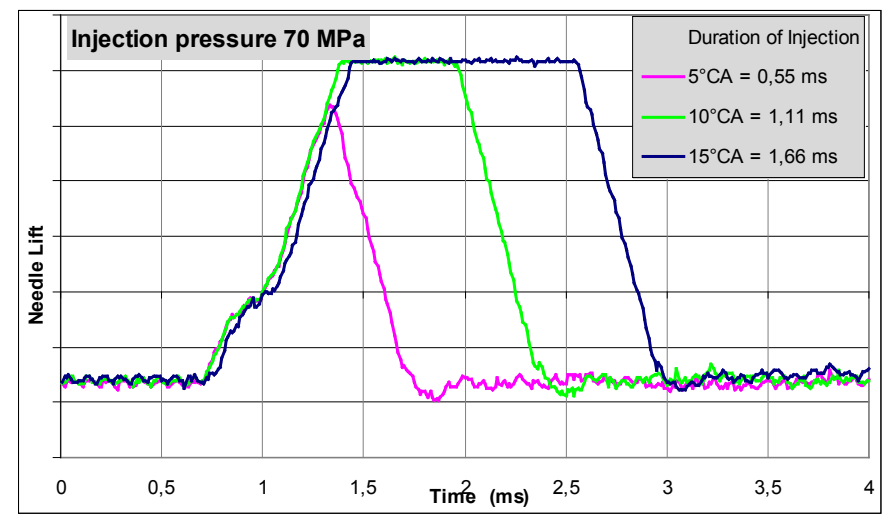

FIGURE 10: Plot of the needle stroke at the input pressure of $70 \mathrm{MPa}$ and varied periods of solenoid actuation.

OBRÁZEK 10: Průběh zdvihu jehly při vstupním tlaku $70 \mathrm{MPa}$ a různé délce aktivace solenoidu. losses have a negative impact on the injectors. It shows only that the operation of the injector becomes energy-demanding in the area above $140 \mathrm{MPa}$ and thus the efficiency of the entire system decreases.

From Figure 10 it follows that at low pressure and short period of actuation of the solenoid corresponding to $5^{\circ} \mathrm{CA}$, the needle in the injector nozzle will not open fully.

From Figure 11 it follows that at high pressures, the needle in the injector nozzle will open fully even during a short period of actuation of the solenoid. A positive fact is the verification of higher velocity of nozzle opening due to higher pressures.

The experiment was complemented by measuring the course of the fuel pressures in the Rail and on the input of the injector, simultaneously with measuring the course of the strokes of the injector needle.

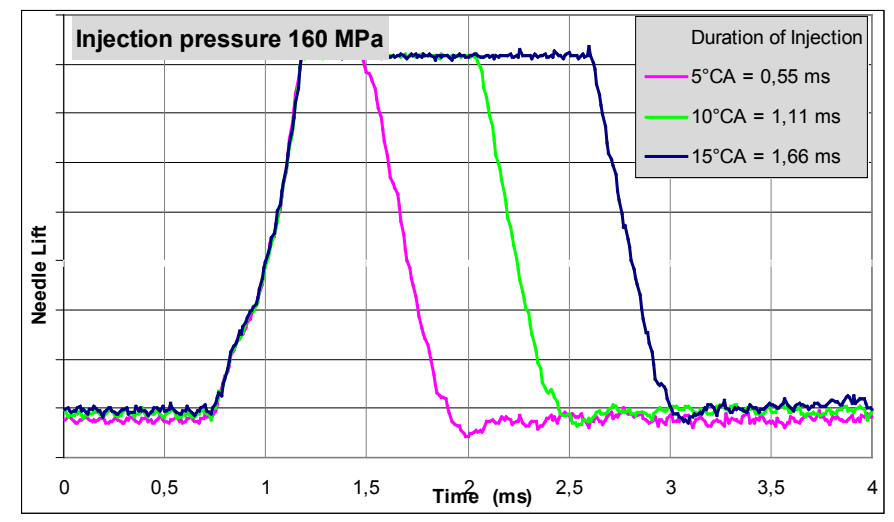

FIGURE 11: Plot of the needle stroke at the input pressure of $160 \mathrm{MPa}$ and varied periods of solenoid actuation

OBRÁZEK 11: Průběh zdvihu jehly prì vstupním tlaku $160 \mathrm{MPa}$ a různé délce aktivace solenoidu. 


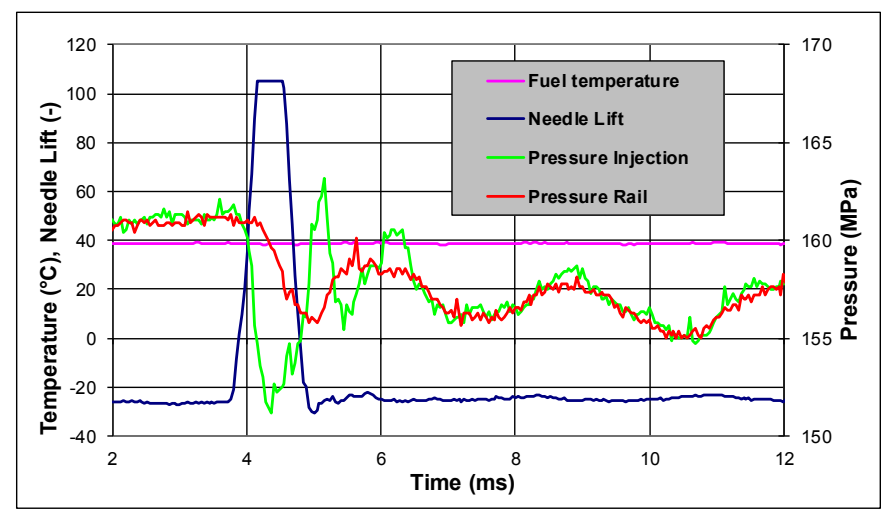

FIGURE 12: Plots of the fuel pressures, needle lift for the input pressure $160 \mathrm{MPa}, 1,500 \mathrm{~min}^{-1}$ and the period of opening $5^{\circ} \mathrm{CA}$

OBRÁZEK 12: Průběh tlaků paliva, zdvihu jehly pro vstupní tlaku $160 \mathrm{MPa}$, $1500 \mathrm{~min}^{-1}$, a délku aktivace solenoidu $5^{\circ} \mathrm{CA}$.

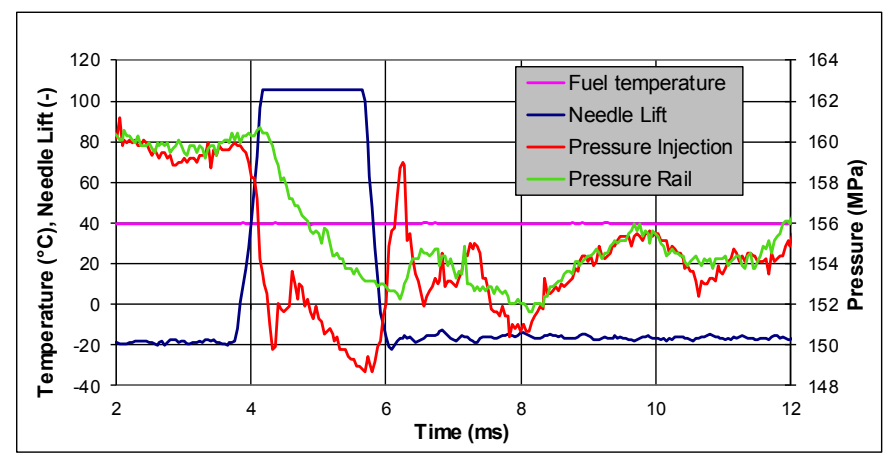

FIGURE 13: Plots of the fuel pressures, needle lift for the input pressure $160 \mathrm{MPa}, 1,500 \mathrm{~min}-1$ and the period of opening $15^{\circ} \mathrm{CA}$

OBRÁZEK 13: Průběh tlaků paliva, zdvihu jehly pro vstupní tlaku 160 $\mathrm{MPa}, 1500 \mathrm{~min}^{-1}$, a délku aktivace solenoidu $15^{\circ} \mathrm{CA}$.

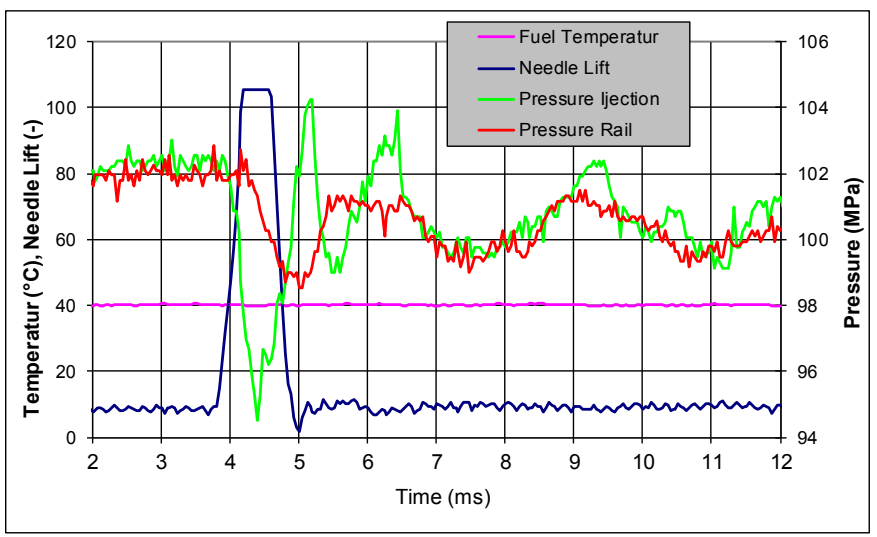

FIGURE 14: Plots of the fuel pressures, needle lift for the input pressure $100 \mathrm{MPa}, 1,500 \mathrm{~m}^{\mathrm{in}}-1$ and the period of opening $5^{\circ} \mathrm{CA}$ OBRÁZEK 14: Průběh tlaků paliva, zdvihu jehly pro vstupní tlaku 100 $\mathrm{MPa}, 1500 \mathrm{~m}^{\text {in }}-1$, a délku aktivace solenoidu $5^{\circ} \mathrm{CA}$.

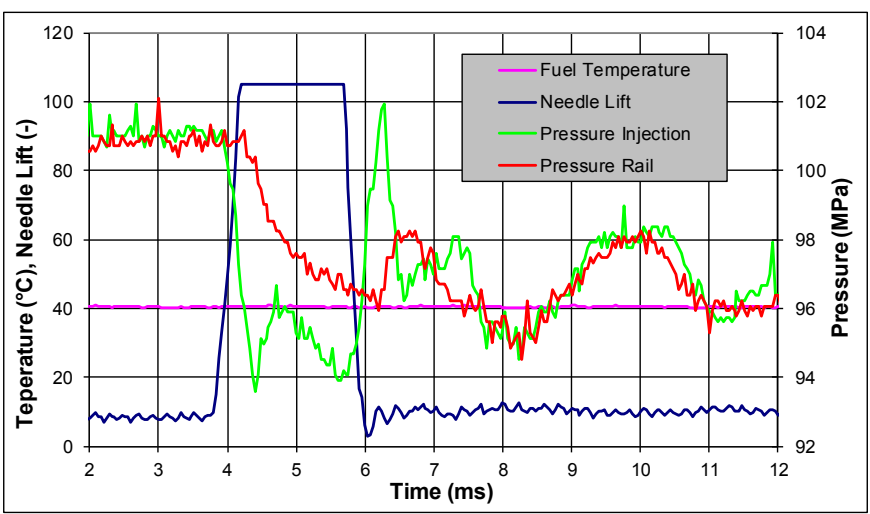

FIGURE 15: Plots of the fuel pressures, needle lift for the input pressure $100 \mathrm{MPa}, 1,500 \mathrm{~min}^{-1}$ and the period of opening $15^{\circ} \mathrm{CA}$

OBRÁZEK 15: Průběh tlaků paliva, zdvihu jehly pro vstupní tlaku $100 \mathrm{MPa}$, $1500 \mathrm{~min}^{-1}$, a délku aktivace solenoidu $15^{\circ} \mathrm{CA}$.

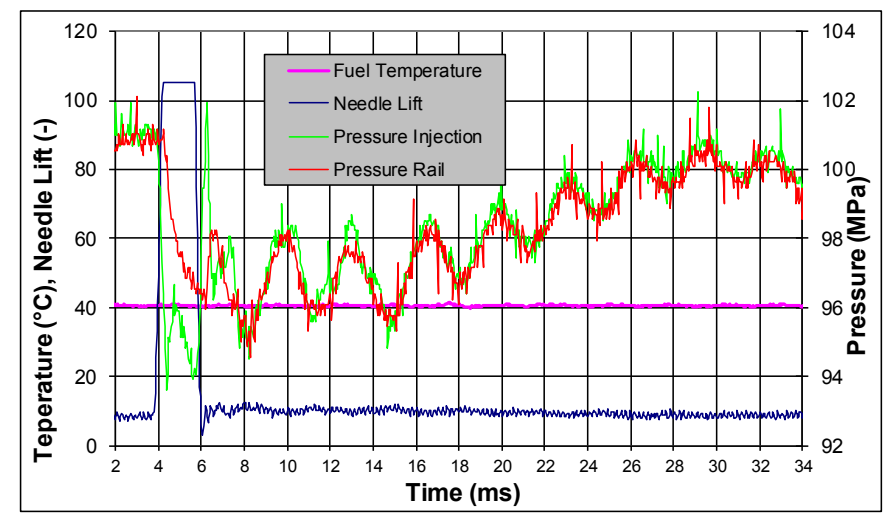

FIGURE 16: Plots of fuel pressures, lift of the needle for the input pressure $100 \mathrm{MPa}, 1,500 \mathrm{~min}^{-1}$ and the period of opening $15^{\circ} \mathrm{CA}$ OBRÁZEK 16: Průběh tlaků paliva, zdvihu jehly pro vstupní tlaku 100 $\mathrm{MPa}, 1500 \mathrm{~min}^{-1}$, a délku aktivace solenoidu $15^{\circ} \mathrm{CA}$.

Figures 12 and 15 show selected plots of fuel pressure at the input to the injector and in the Rail as a function of the stroke of the needle of the injection nozzle. The pressure responses to the movement of the needle are clear, in particular the decrease in pressure at the input to the injector, and the subsequent decrease in pressure in the Rail. The closing of the injection nozzle is accompanied by a contrary trend, namely a steep increase in the pressure, in some cases by up to $10 \mathrm{MPa}$. From the plots it follows that this problem of high fluctuation of pressure occurs, in particular, at the combination of a high injection pressure and very low values of periods of opening of the injection nozzle, namely $5^{\circ} \mathrm{KH}$. In such cases, a change in pressure at the input of the injector has a considerable influence on the course and the fluctuation of the pressure in the Rail.

The pressures revert to their original values prior to the actuation of the fuel injection after 15-25 ms, depending upon the length of actuation and the magnitude of the input pressure, see Figure 16 


\section{CONCLUSION}

The objective of this paper is verification of the trends of mass flow through leaks in individual components of the injector of the Common Rail high-pressure system, both with the closed nozzle and at its opening in real periods and cycles given by the frequency of engine rpm.

Of importance is the established level of leaks at the closed nozzle, where the standard is $100 \%$ tightness of the needle in the nozzle, allowing for a certain level of leak rate in the line of the fuel return flow back to the tank.

Of interest is the detection and verification of the ability to separate the flow through the leak of the ball valve of the solenoid and the internal leak rate of the guiding of the nozzle and of the control cylindrical piston in the currently employed type of injector. This concept will contribute to the testing of manufacturing options for mutual mating, easier identification of manufacturing deviations and ascertainment of possible operating wear and tear.

The monitoring of the distribution of mass flows during modelling of actuation of the solenoid at a frequency and period relevant to the engine regime, provides a better idea of the admissible level of return flow of the fuel back to the tank without influencing the function of the fuel system.

The monitoring of the course of the movement of the needle is of importance for future research, which will investigate its relationship with the movement of the stroke of the solenoid and dynamics of the input pressure.

\section{ACKNOWLEDGEMENT}

The results of this project L01201 were obtained through the financial support of the Ministry of Education, Youth and Sports in the framework of the targeted support of the "National Programme for Sustainability I" and the OPR\&DI project Centre for Nanomaterials, Advanced Technologies and Innovation CZ.1.05/2.1.00/01.0005 and Technological Agency, Czech Republic, Centres of Competence programme, project \# TE01020020 Josef Božek Competence Centre for Automotive Industry

\section{REFERENCES}

[1] SAGI H.: Advanced Leak Test Methods. ATC, Inc., www.atcins.net

[2] SCHOLZ C., STARÝ P. Experimental Stand for Research of Common-Rail Injectors, In: XLI International Scientific Conference of Czech and Slovak Universities Departments and Institutions Dealing with the Research of Combustion Engines, 2010 Liberec, pp. 277-287.

ISBN 978-80-7372-632-4.

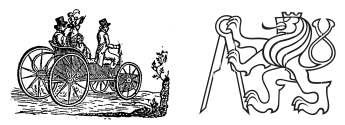

